\title{
A CORRECTION
}

With reference to an article entitled "Three Undescribed Genera and Species of Encyrtidae.......Parasitic in Coccids" published in the Proc. Ind. Acad. Sci., Vol. LXIII, Sec. B, February 1966, the Author has learnt from Prof. O. Peck that one of the generic names used by him, viz., Paraleurocerus, is preoccupied by Paraleurocerus Girault (Jl. N.Y.ent. Soc., 23: 172, 1915) with Paraleurocerus bicoloripes Girault, as the type species. A new name (generic) 'Praleurocerus' has been selected for the replacement of the first one and the help received from Prof. Peck is much appreciated.

Man Mohan Agarwal. 